\title{
PENGARUH KELOMPOK MANAJEMEN PUNCAK TERHADAP FINANCIAL DISTRESS : STUDI KASUS PADA PERUSAHAAN PERBANKAN DI INDONESIA
}

\author{
Moh. Baqir Ainun $a^{*}$ \\ a Universitas Airlangga \\ Diterima Mei 2019; Disetujui Juni 2019; Dipublikasikan November 2019
}

\begin{abstract}
Abstrak
Penelitian ini bertujuan untuk mengidentifikasi pengaruh antara kelompok manajemen puncak terhadap financial distress. Penelitian ini menggunakan sampel perusahaan perbankan yang terdaftar di Bursa Efek Indonesia pada tahun 2016. Teknik analisis data yang digunakan dalam metode penelitian ini menggunakan analisis regresi berganda dimana variabel kontrol dalam penelitian ini adalah Retur On Asset (ROA), Biaya Operasional terhadap Pendapatan Operasional (BOPO), Capital Adequacy Ratio (CAR), Loan to Deposite Ratio (LDR), dan Cash Ratio (CR). Hasil penelitian ini mendukung teori stewardship dimana kelompok manajemen puncak menganggap bahwa kepercayaan yang diberikan pemegang saham untuk mengelola perusahaan merupakan amanat yang harus dijaga sehingga perbedaan struktur kelompok manajemen puncak tidak akan mempengaruhi motivasi mereka untuk menghindari financial ditress. Hasil penelitian menunjukkan bahwa kelompok manajemen puncak tidak berpengaruh signifikan terhadap financial distress. Hal ini terjadi karena bagaimanapun kondisi dan struktur kelompok manajemen puncak dalam perusahaan tetap mempunyai tujuan yang sama yaitu untuk menghindari terjadinya financial distress.
\end{abstract}

Kata Kunci: Kelompok Manajemen Puncak, Tata kelola Perusahaan, Financial Distress, Bursa Efek Indonesia.

\begin{abstract}
This study aims to identify the influence between top management related to financial distress. This study uses data of banking who listed on the Indonesia Stock Exchange in 2016. The data analysis technique in this research using multiple regression analysis method with the control variable; Return on Assets (ROA), Operational Costs to Operating Income (BOPO), Capital Adequacy Ratio (CAR), Loan to Deposit Ratio (LDR), and Cash Ratio (CR). The study discusses to support the stewardship theory that considers the top management group to have a mandate to the shareholders to manage the company and maintain the organization. However, the differences in the structure of the top management group will not affect their motivation to avoid financial stress. The results showed that the top management group had no significant effect on financial distress. This result is also shown the condition and structure of the top management group in the company still has the same goal which is to avoid financial distress.
\end{abstract}

Keyword: Top Management Team, Good Corporate Governance, Financial Distress, Indonesian Stock Exchange

How To Cite: Ainun, Moh Baqir (2019) Pengaruh Kelompok Manajemen Puncak Terhadap Financial Distress: Studi Kasus Pada Perusahaan Perbankan Di Indonesia. Jurnal Akuntansi dan Bisnis: Jurnal Program Studi Akuntansi, 5 (2): 88-93

* email: moh.baqir.ainun-2018@feb.unair.ac.id

\section{PENDAHULUAN}

Keberlangsungan perusahaan dengan kinerja yang baik merupakan harapan dari pihak-pihak yang terlibat dalam perusahaan tersebut baik pengelola perusahaan maupun pemegang saham. Namun dalam praktiknya tidak selamanya sama dengan keinginan dari pengelola maupun pemegang saham. Salah satu kondisi yang tidak 
diharapkan seperti terjadinya kesulitan keuangan atau financial distress. Financial distress merupakan kondisi dimana perusahaan mengalami kesulitan keuangan yang salah satunya ditandai dengan kondisi laba yang negatif (Widarjo \& Setiawan, 2009).

Pihak yang paling bertanggung jawab dalam kondisi perusahaan yang mengalami financial distress adalah Direksi. Hal ini karena Direksi sebagai organ perusahaan bertugas dan bertanggungjawab secara kolegal dalam mengelola perusahaan. Direksi bertanggung jawab terhadap pengelolaan perusahaan agar dapat menghasilkan keuntungan (proftability) dan juga untuk memastikan kesinambungan usaha perusahaan (Bodroastuti, T. 2009). Dewan Direksi dalam sebuah perusahaan secara bersama-sama harus melaksanakan tugas masing-masing sesuai dengan pembagian tugas dan wewenangnya. Hambrick (2007) menyatakan bahwa organisasi yang memiliki kepemimpinan yang kompleks akan menciptakan pengambilan keputusan yang dihasilkan dari interaksi dan kemampuan seluruh anggota manajemen puncak. Sehingga karakteristik dari kelompok manajemen puncak (Top Management Team/TMT) mempunyai keterkaitan yang lebih kuat terhadap kinerja organisasi dari pada dengan karakteristik menejemen puncak individual (CEO). Tingkat distribusi dari karakteristik anggota manajemen puncak yang lebih kuat akan menciptakan perilaku strategis yang condong pada karakteristik yang lebih kuat tersebut.

Dalam perusahaan perbankan, bagaimana manajemen dalam mengelola pelayanan dan menjaga hubungan dengan nasabah merupakan salah satu cara untuk meningkatkan kinerja perusahaan (Anshari, 2019), sehingga kinerja perusahaan yang baik tentu akan menekan peluang untuk mengalami financial distress dalam perusahaan (Geng, Bose, \& Chen, 2015). Manajemen dalam hal ini tentu sekelompok manajemen puncak (TMT) yang saling bersinergi dalam melaksanakan tugas dan tanggung jawab sesuai dengan wewenangnya. Efisiensi yang dilakukan oleh dewan merupakan salah satu penentu financial distress sehingga tata kelola perusahaan yang lemah akan meningkatkan kemungkinan terjadinya financial distress. Hal tersebut menunjukkan bahwa komposisi struktur dewan seperti ukuran dewan dan proporsi dewan independen harus diperiksa terkait dengan financial distress dalam perusahaan (Manzaneque, Priego, \& Merino, 2016; Miglani, Ahmed, \& Henry, 2015).

Nasser, E. M., \& Aryati, T. (2000) berargumen untuk kondisi financial distress di Indonesia pada sektor perbankan yakni dengan melihat beberapa penyebabnya diantaranya semakin meningkatnya kredit bermasalah, dampak likuidasi, turunnya permodalan, pelanggaran batas maksimum pemberian kredit dan ketidakprofesionalan pihak management menjadi faktor penentu dalam kondisi financial distress di Indonesia. Ismawati, K., \& Istria, P. C. (2015) juga menjelaskan bahwa variabel BOPO juga menjadi salah satu faktor penentu utama dalam terjadinya financial distress di Indonesia. Selanjutnya penelitian ini bertujuan untuk menguji pengaruh karakteristik dari kelompok manajemen puncak (TMT) terhadap terjadinya financial distress pada industri perbankan. Hasil dari penelitian ini diharapkan dapat menambah literatur tentang pentingnya kelompok manajemen puncak (TMT) dalam menentukan kinerja perusahaan dan mencegah terjadinya financial distress yang berujung pada kebangkrutan.

\section{METODE PENELITIAN}

Variabel dependen dalam penelitian ini adalah financial distress. Pengukuran yang digunakan dalam penlitian ini adalah dengan menggunakan kategori yaitu 1 untuk perusahaan yang mengalami financial distress dan 0 untuk perusahaan yang sehat. Adapun kategori perusahaan yang mengalami financial distress adalah perusahaan yang 
mengalami laba negatif (Widarjo \& Setiawan, 2009). Variabel independen dalam penelitian ini adalah karakteristik kelompok manajemen puncak (TMT) meliputi ukuran dewan direksi yang diukur dari jumlah dewan direksi di perusahaan, ukuran dewan komisaris yang diukur dari jumlah dewan komisaris, dan proporsi komisaris independen yang diukur dengan persentase komisaris independen di dewan komisaris perusahaan. Untuk variabel kontrol dalam penelitian ini adalah Retur On Asset (ROA), Biaya Operasional terhadap Pendapatan Operasional (BOPO), Capital Adequacy Ratio (CAR), Loan to Deposite Ratio (LDR), dan Cash Ratio (CR). Untuk Populasi dan Sample yang digunakan dalam penelitian ini adalah seluruh data perusahaan perbankan yang terdaftar di Bursa Efek Indonesia Tahun 2016 yang dijustifikasi sebanyak 22 Perusahaan.

\section{Model Analisis}

Analisis yang digunakan dalam penelitian ini adalah regresi linier berganda dengan model regresi sebagai berikut:

$\mathrm{FD}=\alpha+\beta 1 \mathrm{DSIZE}+\beta 2 \%$ KOMSIZE $+\beta 3 \%$ KOMINDEP $+\beta 4 \mathrm{ROA}+\beta 5 \mathrm{BOPO}+$ $\beta 6 \mathrm{CAR}+\beta 7 \mathrm{LDR}+\beta 8 \mathrm{CR}+\varepsilon$

Dimana:

$\begin{array}{ll}\text { FD } & : \text { Financial Distress } \\ \alpha & : \text { Konstansta } \\ \text { DSIZE } & \text { : Jumlah Dewan Direksi } \\ \text { KOMSIZE } & \text { : Jumlah Dewan Komisaris } \\ \% \text { KOMINDEP } & \text { : Persentase Komisaris Independen dalam Dewan Direksi } \\ \text { ROA } & \text { : Return On Asset } \\ \text { BOPO } & \text { : Biaya Operasional terhadap Pendapatan Operasional } \\ \text { CAR } & : \text { Capital Adequacy Ratio } \\ \text { LDR } & : \text { Loan to Deposite Ratio } \\ \text { CR } & : \text { Cash Ratio } \\ \varepsilon & : \text { Error }\end{array}$

\section{HASIL DAN PEMBAHASAN}

Tabel 1 dibawah ini menunjukkan hasil yang terdiri dari statistik deskriptif, uji asumsi klasik, dan uji regresi sebagai berikut.

Tabel 1 Statistik Deskriptif

\begin{tabular}{lccccc}
\hline & $\mathrm{N}$ & Minimum & Maximum & Mean & Std. Deviation \\
\hline Ukuran Direksi (X1) & 22 & 3 & 11 & 7.05 & 2.400 \\
Ukuran Komisaris (X2) & 22 & 3 & 8 & 4.91 & 1.659 \\
\%Kom Indep (X3) & 22 & .38 & .75 & .5629 & .09146 \\
ROA (X4) & 22 & -11.06 & 4.07 & .0018 & 3.81220 \\
BOP0 (X5) & 22 & 21.15 & 345.15 & 106.3232 & 92.85608 \\
CAR (X6) & 22 & 11.47 & 34.50 & 20.0473 & 5.31798 \\
LDR (X7) & 22 & 53.66 & 122.61 & 86.4214 & 14.23104 \\
CR (X8) & 22 & 13.78 & 108.10 & 31.7086 & 19.35865 \\
\hline
\end{tabular}


Tabel 2 Uji Multikolinieritas

\begin{tabular}{|c|c|c|}
\hline \multirow[t]{2}{*}{ Model } & \multicolumn{2}{|c|}{ Collinearity Statistics } \\
\hline & Tolerance & VIF \\
\hline Ukuran Direksi (X1) & .319 & 3.131 \\
\hline Ukuran Komisaris (X3) & .275 & 3.632 \\
\hline \%Kom Indep (X4) & .486 & 2.059 \\
\hline ROA (X5) & .151 & 6.636 \\
\hline BOPO (X6) & .172 & 5.804 \\
\hline CAR (X7) & .880 & 1.136 \\
\hline LDR (X8) & .749 & 1.335 \\
\hline CR (X9) & .715 & 1.399 \\
\hline
\end{tabular}

Dari Tabel 2 diatas dapat diketahui bahwa angka VIF berada di bawah angka 10\% dimana standar error dalam penelitian ini ditetapkan. Hasil ini menunjukkan bahwa model dalam penelitian ini bebas dari multikolinieritas. Multikolinieritas merupakan asumsi klasik yang harus dipenuhi untuk memastikan bahwa tidak ada korelasi yang terjadi antar variabel independen (Ghozali, 2013). Kemudian secara hasil menunjukkan bahwa dalam uji Heterokedastisitas diketahui sebaran terlihat secara acak. Hal ini menunjukkan bahwa model dalam penelitian ini bebas dari heterokedastisitas. Uji heterokedastisitas merupakan uji asumsi klasik yang ditujukan untuk mengetahui ketidak samaan variance dalam suatu model penelitian (Ghozali, 2013).

Tabel 3 Uji Regresi

\begin{tabular}{|c|c|c|c|c|}
\hline \multirow[t]{2}{*}{ Model } & \multicolumn{2}{|c|}{$\begin{array}{l}\text { Unstandardized } \\
\text { Coefficients }\end{array}$} & \multirow{2}{*}{$\begin{array}{c}\text { Standardized } \\
\text { Coefficients }\end{array}$} & \multirow[t]{2}{*}{ Sig. } \\
\hline & $\mathrm{B}$ & Std. Error & & \\
\hline (Constant) & 1.368 & 1.689 & & .433 \\
\hline Ukuran Direksi (X1) & -.023 & .085 & -.109 & .791 \\
\hline Ukuran Komisaris (X3) & .085 & .132 & .281 & .530 \\
\hline \%Kom Indep (X4) & -1.001 & 1.806 & -.182 & .589 \\
\hline ROA (X5) & .062 & .078 & .469 & .440 \\
\hline BOPO (X6) & .000 & .003 & -.087 & .877 \\
\hline CAR (X7) & .010 & .023 & .102 & .683 \\
\hline LDR (X8) & -.008 & .009 & -.239 & .381 \\
\hline $\mathrm{CR}(\mathrm{X} 9)$ & -.002 & .007 & -.077 & .780 \\
\hline
\end{tabular}

Dari Tabel 3 di atas dapat diketahui bahwa nilai sig dari variabel ukuran Direksi, ukuran Komisaris dan persentase Komisaris independen lebih besar dari standar error yang ditetapkan dalam penelitian ini sebesar $10 \%(0,10)$. Hal ini menujukkan bahwa ukuran Direksi, ukuran Komisaris, dan persentase Komisaris independen tidak berpengaruh terhadap financial distress. Hal ini sejalan dengan penelitian yang dilakukan oleh Rahmawati dan Khoiruddin (2017) dan Widyasaputri (2012) yang menyatakan bahwa ukuran dewan Komisaris tidak berpengaruh signifikan terhadap financial distress. Selain itu, dalam penelitian lain Cinantya and Merkusiwati (2015) menyatakan bahwa ukuran dewan Direksi dan proporsi Komisaris independen tidak berpengaruh terhadap financial distress.

Davis, Schoorman, dan Donaldson (1997) melalui teori stewardship menyatakan bahwa manajer tidak termotivasi oleh tujuan individual, namun manajer termotivasi untuk sepenuhnya mewujudkan tujuan dari pemilik saham. Manajer menganggap bahwa tanggung jawab yang diberikan sebagai pengelola perusahaan merupakan sebuah 
amanah yang harus dijaga dengan baik, sehingga bagaimanapun struktur dari dewan dalam sebuah perusahaan, manajer akan tetap sama-sama berusaha semaksimal mungkin untuk meningkatkan kinerja perusahaan dan menghindari financial distress (Miglani et al., 2015).

Terkait dengan financial ditress dalam penelitian ini, kelompok manajemen puncak dari perusahaan perbankan akan sama-sama berusaha untuk tidak mengalami financial distress sehingga perbedaan kelompok manajemen puncak tidak memberikan pengaruh terhadap terjadinya financial distress pada perusahaan. Bagaimanapun komposisi dari kelompok manajemen puncak, tidak satupun yang ingin perusahaan yang dipimpinnya mengalami financial distress. Dari hasil penelitian ini dapat disimpulkan bahwa kelompok manajemen puncak perusahaan perbankan di Indonesia benar-benar mengemban amanah untuk bekerja semaksimal mungkin demi kepentingan pemegang saham dan menghindari financial ditress terjadi pada perusahaan sesuai dengan teori stewardship yang dikemukakan oleh (Davis et al., 1997).

\section{SIMPULAN}

Dari hasil penelitian yag telah dijelaskan dapat diketahui bahwa kelompok manajemen puncak (ukuran Direksi, ukuran Komisaris, dan persentase Komisaris independen) tidak berpengaruh terhadap financial distress. Hasil penelitian ini memperkaya hasil pengujian empiris bahwa ukuran Direksi, ukuran Komisaris, dan persentase Komisaris independen dalam dewan Komisaris tidak mempengaruhi terjadinya financial distress pada perusahaan perbankan. Hal ini terjadi karena kelompok manajemen puncak baik ukuran dewan Direksi yang kecil maupun besar, ukuran Komisaris yang kecil maupun besar, dan persentase Komisaris independen yang kecil maupun besar memiliki tujuan yang sama untuk melaksanakan tanggung jawab sebaikbaiknya demi tujuan dari pemegang saham sesuai dengan teori stewardship. Kami melimitasi studi ini dengan menganbil tahun 2016 saja untuk melihat kembali efek sebelum dan setelah pemilihan umum negara Indonesia untuk menjadi kajian selanjutnya.

\section{DAFTAR PUSTAKA}

Anshari, R. (2019). Pengaruh customer relationship management (CRM) terhadap kinerja perusahaan pada industri perbankan Indonesia. Akuntabel, 16(1), 122-127.

Bodroastuti, T. (2009). Pengaruh Struktur Corporate Governance terhadap Financial Distress. Jurnal Aset, 11(2), 170-182.

Cinantya, I. G. A. A. P., \& Merkusiwati, N. K. L. A. (2015). Pengaruh Corporate Governance, Financial Indicators, dan Ukuran Perusahaan pada Financial Distress. E-Jurnal Akuntansi Universitas Udayana, 10(3), 897-915.

Davis, J. H., Schoorman, F. D., \& Donaldson, L. (1997). Toward a Stewardship Theory of Management. Academy of management review, 22(1), 20-47.

Geng, R., Bose, I., \& Chen, X. (2015). Prediction of financial distress: An empirical study of listed Chinese companies using data mining. European Journal of Operational Research, 236-247.

Ghozali, I. (2013). Aplikasi Analisis Multivariate dengan Program SPSS, Edisi ketujuh. Semarang: Badan Penerbit Universitas Diponegoro (BPUD).

Hambrick, D. C. (2007). Upper echelons theory: An update: Academy of Management Briarcliff Manor, NY 10510.

Ismawati, K., \& Istria, P. C. (2015). Detektor Financial distress Perusahaan Perbankan Indonesia. Jurnal Ekonomi Bisnis dan Kewirausahaan, 4(1), 6-29.

Pedoman Umum Good Corporate Governance Indonesia (2006).

Manzaneque, M., Priego, A. M., \& Merino, E. (2016). Corporate governance effect on financial distress likelihood: Evidence from Spain. REVISTA DE CONTABILIDAD, 19(1), 111-121. 
Miglani, S., Ahmed, K., \& Henry, D. (2015). Voluntary corporate governance structure and financial distress: Evidence from Australia. Journal of Contemporary Accounting \& Economics, 11, 18-30.

Nasser, E. M., \& Aryati, T. (2000). Model analisis CAMEL untuk memprediksi financial distress pada sektor perbankan yang go public. Indonesian Journal of Accounting and Auditing, 4(2), 111-130.

Rahmawati, D., \& Khoiruddin, M. (2017). Pengaruh Corporate Governance dan Kinerja Keuangan dalam Memprediksi Kondisi Financial Distress. Management Analysis Journal, 6(1), 1-12.

Widarjo, W., \& Setiawan, D. (2009). Pengaruh Rasio Keuangan Terhadap Kondisi Financial Distress Perusahaan Otomotif. Jurnal Bisnis dan Akuntansi, 11(2), 107-119.

Widyasaputri, E. (2012). Analisis Mekanisme Corporate Governance pada Perusahaan yang Mengalami Kondisi Financial Distress. Accounting Analysis Journal, 1(2), 1-8. 